\title{
Working from afar A new trend for librarianship
}

"A lot of us work from bome on occasion, and whenever I talk to my colleagues about it, without exception, we feel that a few hours spent working away from the office are more productive than if we had spent them chained to our desks. "-Andrew Pace

"I couldn't stand the thought of being at home all day while everyone else was working at the library.... A world of telecommuters sounds like a terribly lonely place."-Will Manley ${ }^{2}$

$\mathbf{T}$ elecommuting, which once seemed impractical for librarians, is swiftly becoming a viable option for employees in both technical services and public services. According to the Bureau of Labor Statistics, by May 2004, 20.7 million people regularly worked from home at least once per week as part of their primary job. This number represented 15 percent of total nonagricultural employment-and 30 percent of managerial/professional positions. ${ }^{3}$

Societal changes such as increased commuting time, rising numbers of dual working-parents, and an explosion of technology that facilitates remote work have fueled both the desirability and the feasibility of alternative work arrangements. Traditionally, librarians have been tethered to a facility either because their public service role demands face-to-face interaction or because they work with materials housed in the building. As collection formats and service mechanisms change, however, librarians may be poised to take advantage of more flexible scheduling arrangements.
In spring 2007, I embarked on a sixmonth telecommuting experiment between Washington, D.C., and Logan, Utah, that proved to me that most of my daily responsibilities are perfectly compatible with a more flexible work arrangement.

My husband and are both faculty members at Utah State University (USU): myself as an electronic resources librarian and he as a history professor. In summer 2006, my husband won a prestigious fellowship at the Library of Congress. Acceptance of this grant required his presence in Washington, D.C., for six months beginning in January 2007. Because we had a toddler, we agreed that it would be unacceptable to split the family for such a lengthy stretch. We further agreed that unless I was able to join him in Washington, either he would have to decline the grant, or I would have to, at least temporarily, step-down from my own tenure-track position at the library. Neither option was appealing to us-and either certainly would have had an extremely negative impact on one of our professional lives.

I determined that I would craft a proposal to the library director permitting me to restructure my job, temporarily reducing my hours by 25 percent and working the remaining hours through telecommuting. This proposal was not without risk to the library, as it is not particularly usual in our field for practitioners to work remotely. However, I felt that my job would naturally fit well

Jennifer Duncan is electronic resources librarian at Utah State University, e-mail: jennifer.duncan@usu.edu

(c) 2008 Jennifer Duncan 
with such an arrangement because, as the electronic resources librarian, I manage a virtual collection and most of my work can be done with a phone line and a networked computer. My physical location is not particularly significant, generally speaking.

Library administration agreed to support my proposal. Our associate director for technical services felt very strongly that encouraging flexible work schedules and work/life balance was essential to retention of and morale among staff. ${ }^{4}$ Library administration further agreed to release me from selected committee work as well as to provide me with software and computer clients required to perform my job. However, they were unable to provide me with essential hardware and peripherals. Additionally, they were quite insistent that I return to Logan at least twice during the spring, not an inexpensive proposition.

Fortunately, USU participates in the National Science Foundation's ADVANCE Program, designed to increase the advancement and retention of female scientists and engineers. ${ }^{5}$ USU ADVANCE administers a Transitional Support grant program, open to all women faculty at the university and designed to provide support when research is delayed or interrupted by family or other responsibilities. I thought this grant might be able to provide the necessary financial resources to fund a portion of my telecommuting proposal, thus keeping my career on track.

Happily, ADVANCE awarded me a grant of $\$ 4,500$. I used ADVANCE funds for the following: a MacBook powerful enough to run desktop clients for our Dynix ILS and our Innovative ERM; Parallels software to run Windows on the Mac OS; a Treo smartphone so that I could be on call both via e-mail and voice at all times (between the time change and my reduced work schedule, it was difficult to be tied to my home computer during the full workday); service agreements for both the phone and the laptop, since I did not have systems support; travel to and within Utah twice; and partial com-

\section{Perhaps the greatest personal challenge of working from home is defining a clear boundary between when you are "at work" and "at home"-particularly when dealing with a two-hour time change.}

pensation for cell phone and Internet service, both of which were much more robust - and expensive-than I would have needed for personal use.

During the six months that I was in Washington, I found that I was more than able to keep busy fulfilling my job responsibilities. In fact, there was not much in my daily routine to eliminate. I was able to process invoices through our ILS, (receiving scanned documents from vendors and re-submitting them to our accounting technician); negotiate license agreements and acquire new electronic resources (major negotiations included the Freedom Collection, ARTstor, and NetAdvantage); maintain our existing e-journal and database collections using services such as SerialsSolutions, EBSCOnet, and a homegrown database that populates our Web pages; maintain our ERM including processing coverage loads; close 2007 budgets and propose 2008 e-resource budgets; help develop and post to a public blog for the library; and select books for the History department, my liaison area.

I enhanced e-journal access by incorporating brief catalog records into the online catalog, where they had never been before. I also remained the primary support contact for troubleshooting patron e-resource problems. (In fact, since so many support calls involve problems with remote access, I actually felt that I was better able to diagnose problems. I also think that I developed more empathy for the problems and concerns of our off-campus patrons, which I will certainly carry forward now that I am back on campus.)

Finally, because we lived near College Park, I was able to use the University of Maryland's McKeldin Library to continue my work on a periodicals bibliography. (The $m a$ jor change to my schedule involved regular 
attendance at numerous meetings. I continued to attend major meetings by phone-and was even appointed to the newly formed library dean search committee, which met weekly. However, I did excuse myself from more minor meetings, which, in the end, improved my efficiency. I also noticed that meetings that I attended virtually seemed to run much more quickly.) ${ }^{6}$

After I returned in July 2007, several colleagues, including the director, commented that they were amazed at how responsive I was while working at a distance. Reference librarians were pleased that I was able to resolve database and electronic journal access problems efficiently from 2,000 miles away. My supervisors felt that the experiment had worked. I had endeavored to make my colleagues feel that I was just as available to them as if I had been sitting in my cubicle. And, in fact, I was. For the most part, when I am not telecommuting, I could, theoretically, sit through an entire day and not have any faceto-face interaction if I didn't seek it out-not that I would actually want to do that.

Typical questions and requests occur via email, even between myself and people 20 feet away. The difference when telecommuting was that all interactions had to occur this way and follow-ups involved an e-mail response or a quick call rather than standing up and walking a few feet. So, I got to be a real pro with technologies like Skype (an Internet videoconferencing service) and Adium (a chat client aggregator for Macs); I had an enormous cell phone bill every month-including lots of text messaging. Naturally, e-mail use went through the roof.

\section{Challenges of working from home}

However, I faced numerous day-to-day challenges as well as questions about the longterm viability of telecommuting. Perhaps the greatest personal challenge of working from home is defining a clear boundary between when you are "at work" and "at home" — particularly when dealing with a two-hour time change. This "blurring" of roles occasionally (not surprisingly to skeptics) could result in distractions while I was "on," but also made it difficult for me to relax and shut-down my computer when I was "off." As recommended for telecommuters, I established a daily schedule and lined-up childcare so that I could "go to work" from 10:00 to 4:00. But, this didn't mean that at 4:00 Eastern Time people on Mountain Time stopped having pressing needs ... or that I didn't take calls from students at 10:00 p.m. or while at the National Zoo on the weekend.

A second surprise was how much I came to really appreciate our systems administrators. There is absolutely nothing like trying to maintain all of your own technology to make you appreciate your systems administrators. Problems with networking required hourlong calls with Verizon, Hewlett-Packard, and Apple. A faulty fax required numerous trips to Kinkos. When the printer ran out of ink unexpectedly as I was trying to finalize a license, I had to rush to the office supply store. I will never again underestimate the seamlessness of workplace technology.

Finally, and perhaps most significantly, I came to the conclusion that long-term, day-to-day telecommuting probably is not in the best interest of most library employees and organizations. I think that six months is probably the outside limit of what might be advisable. While I continued to get my work done, probably with more efficiency than ever before, I found that I was missing out on the daily ebb and flow of organizational conversation. While I was in constant phone and electronic contact with my co-workers, I was absent from the casual conversation that happens around the proverbial watercooler-the serendipitous interaction that leads to more cohesive organizational vision and action. This is not to say that I feel as though I missed too much, but rather that I began to feel more like an individual actor as opposed to a member of an ensemble. That said, I did find that my productivity was often much higher when working outside of the office and, if given my druthers, I think

(continues on page 236) 
("Working from afar" continued from page 218)

a day or two a week telecommuting would work great for me.

In the end, I think that this experiment in telecommuting was a success both personally and professionally. My husband and I were able to keep our family together, experience a vibrant city, and continue to further our own professional goals.

Moreover, I demonstrated that telecommuting, either full-time for a limited duration-or for a few days a week on an ongoing basis-is a viable option to consider, one that will provide personal benefit to employees and an increase in productivity for their employers.

\section{Notes}

1. Andrew Pace, "Librarians Not in Libraries," Computers in Libraries 24 (October 2004): 32-35.

2. Will Manley, "Telework, or Watching Television," American Libraries, 33 (April 2002): 124 .

Ed. note: Send your news to: Grants \& Acquisitions, C\&RL News, 50 E. Huron St., Chicago, IL 60611-2795; e-mail: agalloway@ala.org.
3. Bureau of Labor Statistics, "Work at Home in 2004" U.S. Dept. of Labor, Bureau of Labor Statistics, www.bls.gov/news.release /homey.nrO.htm.

4 . For a compelling study on the advantages (to both employers and employees) of policies promoting benefits such as paid leave, childcare, and flexible scheduling, see Barbara Gault and Vicky Lovell, "The Costs and Benefits of Policies to Advance Work/Life Integration," American Behavioral Scientist 49 (May 2006): 1152-64.

5. For information about the USU ADVANCE program, see websites.usu.edu /advance/.

6. Snappy commentary on the advantages and disadvantages of face to face meetings for librarians can be found from Meredith Farkas, "No more f2f meetings . . EVER!" Information Wants to be Free, meredith.wolfwater.com/wordpress/index.php/2007/07/21 /no-more-f2f-meetings-ever/.

7. For a review of the literature on blurring and a study that examines academic parents who frequently work from home, see Stephan Desrochers, Jeanne M. Hilton, and Laurie Larwood, "Preliminary Validation of the WorkFamily Integration-Blurring Scale," Journal of Family Issues 26 (May 2005): 442-66. n 